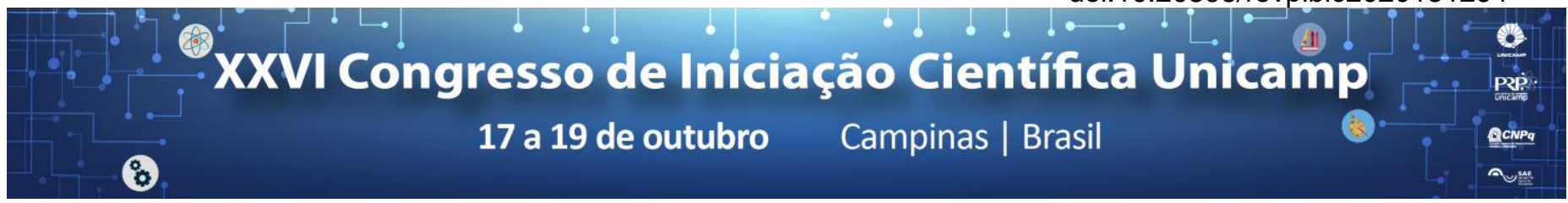

\title{
Determinantes do investimento na indústria de transformação brasileira entre 2003 e 2016
}

\section{Rosylli Oliveira*, Bruno de Conti.}

\begin{abstract}
Resumo
A motivação deste projeto de iniciação científica é a preocupação com a grave crise econômica brasileira atual e seus desdobramentos sociais. Partindo de dois pressupostos, quais sejam, a importância do investimento e da indústria para o crescimento da economia, a pesquisa se destina a encontrar os principais determinantes do investimento na indústria de transformação no período recente (2003-2016). Dessa forma, entender a relação da trajetória de investimento desse setor com a crise e, logo, o que poderia ser feito para recuperar o crescimento, necessário - embora não suficiente para a busca da justiça social.
\end{abstract}

\section{Palavras-chave:}

Indústria de transformação, determinantes do investimento, competitividade.

\section{Introdução}

Em economias monetárias, diante da possibilidade da insuficiência de demanda, o investimento é uma variável crucial porque dele depende o crescimento da renda e do emprego na economia. A dinâmica dos investimentos no período de análise, como mostra a figura ao lado, tem dois momentos marcantes. O investimento começa a crescer na economia brasileira, a partir de 2005, quando o governo Lula faz uma política macroeconômica mais "desenvolvimentista" e, apesar da queda na crise de 2008, rapidamente, ele recupera a sua trajetória ascendente até 2013, ano precedente ao ano da Copa do Mundo, e no qual as expectativas de rendimentos das empresas eram altas. Porém, vale dizer, segundo documentos analisados da CNI e Fiesp, os investimentos na indústria, desde 2011, eram alocados mais em racionalização da produção do que expansão da capacidade produtiva. Desde 2014, então, as taxas de crescimento do investimento agregado são decrescentes. Somou-se aos muitos motivos para a deterioração das expectativas dos empresários, a acentuada crise política, que culminou no impeachment em 2016.

\section{Resultados e Discussão}

$\mathrm{Na}$ visão ortodoxa, a solução da situação do país é aumento da produtividade, possibilitado por uma maior abertura econômica, e aumento da poupança doméstica. Por outro lado, na visão heterodoxa, temos, pelo princípio da demanda efetiva, que é preciso agir de forma anticíclica e impulsionar o gasto público.

De acordo com as leituras realizadas, de modo geral, no Brasil, o problema é a incerteza quanto à lucratividade dos empreendimentos e os elevados custos operacionais. Há uma infraestrutura deficiente, condições de financiamento ruins e alta carga tributária, além disso, não existe um ambiente macroeconômico motivador devido à elevada taxa de juros e ao câmbio valorizado. E para agravar essas dificuldades, há o problema de penetração de produtos importados no mercado interno, que "rouba" a demanda das empresas nacionais.

Vale dizer que a complexidade da crise econômica atual não se restringe a erros ou ausências de políticas econômicas, ela se liga também aos fatores externos. A crise em W, o aumento de capacidade ociosa na China, que estimulam a concorrência, e o aumento dos interesses financeiros são barreiras grandes à recuperação dos investimentos e da economia como um todo.
Figura 1. Trajetória do investimento entre 2000 e 2017.

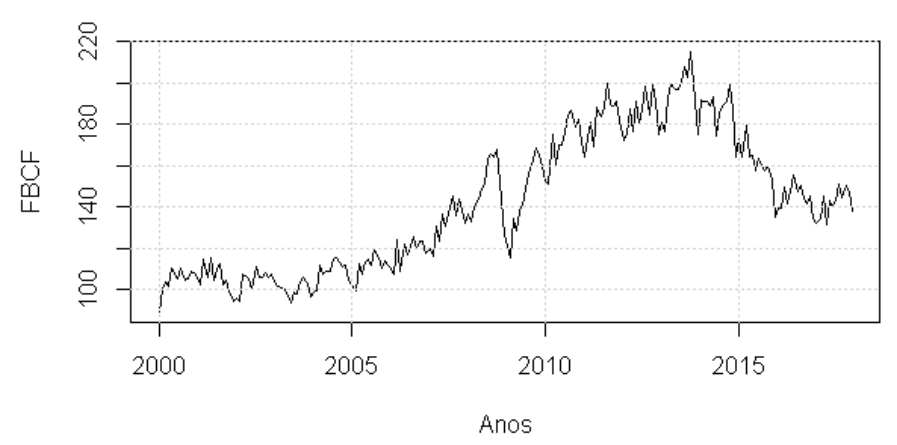

Fonte: IPEADATA, Elaboração própria.

\section{Conclusões}

Diante da perda do mercado consumidor e do aumento dos custos, em defesa do lucro, a indústria reivindicou a reforma trabalhista. Mas é sabido, como de fato se tem comprovado, que a expansão do emprego não depende da redução dos salários, mas do aumento da demanda, ou seja, aumento da procura pelos bens produzidos na economia. Dessa forma, é recolocado no centro da discussão a necessidade de gastos públicos indutores da demanda. Não se justifica um ajuste fiscal num momento de crise, este só a acentua. Pelo contrário, é necessário ampliar o déficit público, financiado, no momento de recuperação da economia, pelo aumento das receitas públicas.

\section{Agradecimentos}

Ao Bruno de Conti, por ser encorajador e mentor. Á minha família e amigos, pelo apoio e compreensão. Ao $\mathrm{PIBIC/CNPq}$, pelo fomento à pesquisa.

Usar esse espaço para referências, seguindo o estilo indicado - Padrão ACS ou ABNT ou Vancouver (letra Times 8). Ex:

Curtis, M. D.; Shiu, K.; Butler, W. M. e Huffmann, J. C. J. Am. Chem. Soc. 1986, 108,3335 . 